\title{
Vibrio Bacterial Concentration in Vaname Shrimp Pond Super Intensive Technology in Takalar District, Indonesia
} \author{
Anshary ${ }^{3}$ \\ ${ }^{1}$ Doctoral Program of Agricultural Science, Hasanuddin University, Makassar, Indonesia \\ ${ }^{2}$ Research Institute for Costal Aquaculture and Fisheries Extension, Indonesia \\ ${ }^{3}$ Faculty of Marine Science and Fisheries, Hasanuddin University, Makassar, Indonesia \\ *Corresponding author
}

A. Indra Jaya Asaad ${ }^{1,2, *}$, Natsir Nessa ${ }^{3}$, Dody Dharmawan Trijuno ${ }^{3}$, Hilal

\begin{abstract}
Research on the concentration of vibrio bacteria in super-intensive shrimp farms has been carried out in August to December 2018 at shrimp pond located in Takalar District, South Sulawesi, Indonesia.This study aims to determine the concentration of vibrio bacteria found in internal shrimp pond system and the dynamics that occur. The results of the study showed that the concentration of vibrio bacteria improved during the day of culture period in the ponds and outlet of the pond. However, the presence of water treatment installation at the location can reduce the concentration, so the concentration ofvibrio bacteria is not a problem if released into coastal waters after being processed in water treatment.
\end{abstract}

Keywords - Vibrio Bacteria, Vaname Shrimp, Super Intensive, Takalar District.

\section{INTRODUCTION}

Aquaculture business activities have undergone system development which includes the application of various methods and innovative technologies to achieve profit incentives and fulfill the targets of the aquaculture development authority. The goal of fulfilling food for local consumption has shifted towards meeting global food needs, one of which is for export.

The variety of current and future challenges faced by the producer sector such as fisheries including aquaculture are the rapidly increasing population needs, the impact of climate change, and environmental degradation on the natural resource base. These three things were revealed in "State of World Fisheries and Aquaculture FAO" in 2018. The increase in population is described as rapidly increasing more than 9 billion people in the mid-twenty-first era. This serious increase will certainly affect the principle of supply and demand for fishery products.

One of the developments in the present time is to increase aquaculture production, especially shrimp farming in ponds, namely the development of super intensive technology shrimp pond systems. Shifting development of a conventional system of brackish water aquaculture towards the direction of super intensive, have consequence on the use of inputs that are larger than the basic pattern of a pond as a semi-open aquaculture system. A common feature of semi-open aquaculture systems is that they are still dependent on nature for the provision of 3 ecological services: temperature, oxygen, assimilation of waste (Tidwell, 2012).

According to RachmanSyah (2014) that this system is the orientation of future shrimp pond systems with a characteristic volume of small cultivation containers, high stocking density, high productivity, minimal waste load and high product competitiveness. In principle, the scope of this technology can be applied to all water sources, namely fresh, brackish and sea water. However, at present, significant developments have been made in coastal ponds with the sea water source.

But on the other hand, the empirical evidence that the application of super intensive shrimp pond technology in addition to producing output in the form of fish / shrimp biomass, also produces waste loads that have the potential to trigger diseases caused by bacteria and viruses. According to Rachman Shah et al (2014) reported the results of his research that the waste of superintensivevaname shrimp 
pondswith a total production of 6-8 tons has exceeded the standard of pond waste load. This has the potential to have an impact on decreasing the quality of the aquatic environment. Furthermore as an undesired output, the decreasing quality of the environment will trigger the emergence of pathogenic bacteria and viruses that can cause shrimp disease and result in mass death. Anshary (2016) argues that the main trigger factors for stress in fish in cultivation systems are high stocking densities, limited land conditions, lack of nutritional standards in supplementary feed, and a tendency to decrease the quality of the aquaculture environment along with maintenance time. Especially in high stocking densities which are the main characteristics of super intensive technology, that will trigger pathogens whose life cycle can immediately spread rapidly to individual fish / shrimp cultivation commodities.

Vibrio harveyi bacteria are found in almost all habitats, such as freshwater, estuary, sea water and soil. These bacteria are disease-causing agents in humans, fish and crustaceans. The entry of pathogenic Vibrio in shrimp farming can be derived from sea water and fries used. Vibrio harveyi Adala h ng kuna disease-causing pathogens lightning strike many aquaculture commodities which caused huge losses in the aquaculture industry (Austin \& Zhang, 2006). Boer et al. (1993) reported that broodstock originating from positive seawater carried fluorescent bacteria so that it spread to fries (larvae) and eventually carried into the ponds.

Based on the problems of the empirical facts from the results of the above research, this paper reports the results of research on the concentration of vibrio bacteria which became undesired output of super intensive technology of vaname shrimp farming in Takalar District, South Sulawesi, Indonesia

\section{MATERIAL AND METHOD}

This research was conducted in August - December 2018 at the location of vaname shrimp farming which applied super intensive technology in Takalar Regency, South Sulawesi Province, Indonesia (Figure1). In that location, two samples of ponds were taken with different densities. In each plot of the farm a bacterial biology sample was taken. In addition, sampling points for bacteria are also taken in parts: (1) clean water reservoirs (as intake water inputs for maintenance); (2) outlets / dumps on pond plots (consisting of plot outlets 1 and 2); (3) outlets / disposal at wastewater treatment installation.

Vibrio bacteria and common bacteria were isolated from sea water, pond water, pond wastewater and wastewater treatment installation. Water samples were taken using a sterile bottle and then taken to the laboratory.The isolation of Vibrio bacteria is carried out by taking $1 \mathrm{~mL}$ of water then diluting it in stages in $9 \mathrm{~mL}$ of physiological solution (Benson, 1985) and culturing on TCBSA (Thiosulfate Citrate Bile Salt Sucrose Agar) media for Vibrio bacteria and on TSA (Trypric Soy Agar) media for general bacteria. The culture method used is the pouring method on the agar plate. The plate method can be used to calculate microorganisms in the sample. A total of $0.1 \mathrm{ml}$ of the sample was taken using a micropipette and using a sterilized glass spreader by dipping it in alcohol \& burning it. Water samples are spread on the surface of the agar with a circular motion on the entire surface of the agar plate. After spread, TCBSA and TSA media were incubated at $35^{\circ} \mathrm{c}$ for $24-48$ hours. After 24 hours an observation of bacterial colonies was grown on the media.

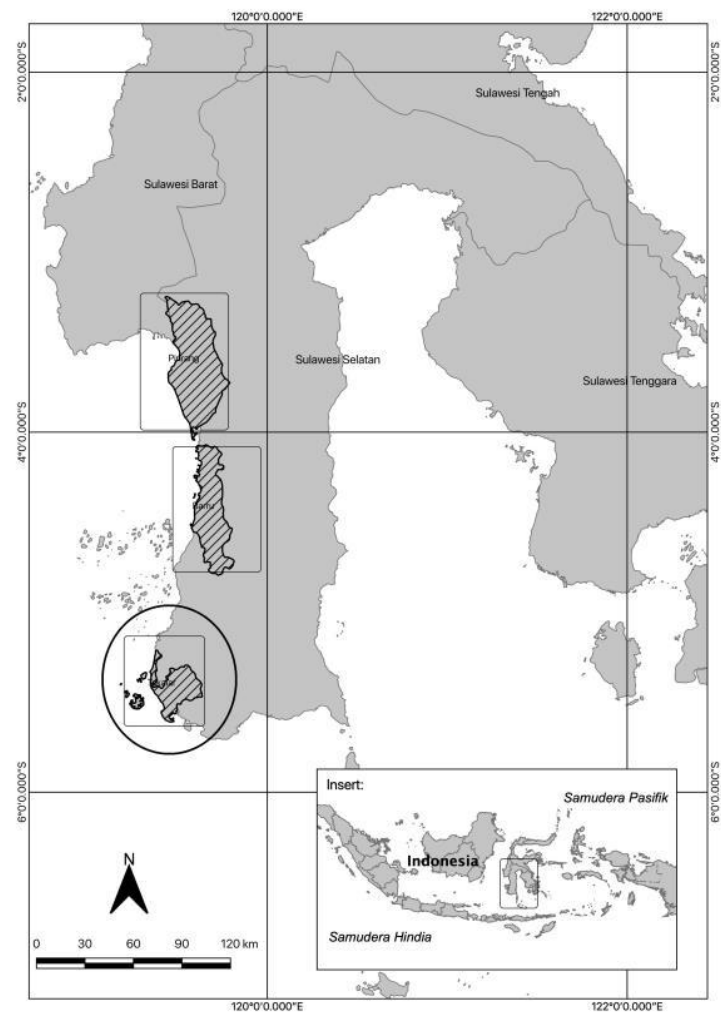

Fig.1: Map of the research location

Calculation of bacterial colonies that were successfully cultured from water samples can be carried out the following day ( Azzizunnisa \& Sree ramulu, 2013).

Bacterial colonies can be calculated using the formula: 
$\frac{\text { Number of bacteria colony }}{\text { Number of plate }} \times \frac{1}{\text { Dilution factor }} \times \frac{1}{\text { Sample volume (cultured) }}$

$10^{3} \mathrm{CFU} / \mathrm{ml}$. This needs to be watched out in cultivation

Whereas to get the ratio of vibrio bacteria to bacteria commonly used formulas:

\section{$\frac{\text { Total Bacteria Vibrio }}{\text { Total Bacteria }} \times 100 \%$}

\section{III.}

\section{RESULTS AND DISCUSSION}

From the graph of Total Vibrio Bacteria (TBV) at the study location (Figure 2 ), there was a tendency that there was an increase during the days of culture (DOC) of vaname shrimp. In pond 1 , the coverage area of $1000 \mathrm{~m}^{2}$ was stocked with 200,000 shrimp fries, while in pond 2, the same pond area was stocked with 400,000 fries. During the 10 dayDOC period at the pond, the total concentration of vibrio bacteria was found in pond 1 and its outlet with a value of around because there is already a concentration of vibrio bacteria even though it is still below $10^{4} \mathrm{CFU} / \mathrm{ml}$. However, at pond outlet 1 , bacterial concentration was found to increase during DOC of 30 days and tended to decrease during the subsequent maintenance period and a slight increase occurred at the end of the maintenance period of 77 days. The trend is the same for farm 2, where the concentration tends to increase in the ponds during the maintenance period, even at the outlet it is found that the concentration jumps more than $10^{4} \mathrm{CFU} / \mathrm{ml}$ during the maintenance period 44 until harvest time. The threshold on Vibrio concentration which can endanger cultivation animals is $10^{4} \mathrm{CFU} / \mathrm{mL}$ (Defoirdt, 2007). According to Taslihan et al., (2004) which states that the minimum limit of common bacteria in waters is $10^{6} \mathrm{CFU}$ / $\mathrm{mL}$.

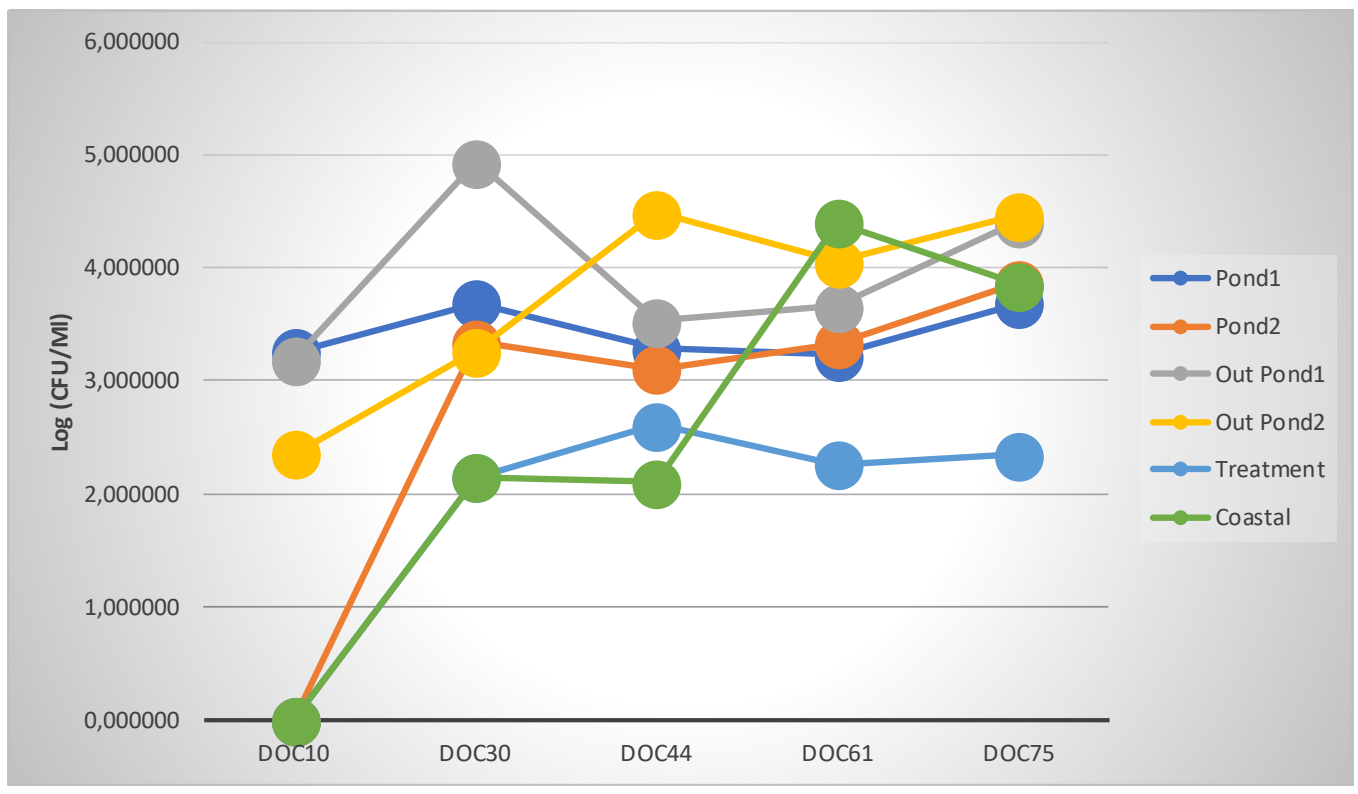

Fig.2: TBV chart at the research location.

There are quite interesting facts, namely the decrease in the concentration of Vibrio bacteria coming out of installation water treatment compared to those coming out of farm outlets 1 and 2. This decrease occurred during the DOC period of shrimp vaname. This illustrates the performance of the water treatment installation at the research site which significantly reduces the concentration of Vibrio bacteria. In September it was seen that the Vibrio concentration in the sea was quite low even lower than the Vibrio concentration from the IPAL outlet. But in October there was a very significant increase in Vibrio concentration in the Sea. This increase in concentration can be information for farm managers not to temporarily withdraw water from the sea for cultivation needs. This is for the efficient use of aquaculture inputs, especially the use of desinfectants to reduce the vibrio concentration which turns out to already exist in marine waters.

In Figure 3, you can see the Total Ratio of Vibrio Bacteria with Total Bacteria. The highest trend ratio in the research location was obtained at the farm outlet. This shows that the output of wastewater from farm ponds is quite high concentration of vibrio bacteria compared to total bacteria in general. This information provides the fact that the high concentration of vibrio bacteria at the disposal of ponds will 
have an environmental impact that receives these waste wastes in this case coastal waters. The optimal function of wastewater treatment is one solution to reduce the waste load including the concentration of the vibrio bacteria. The TBV and TB ratio values indicate that the general bacterial population is higher than the population of Vibrio sp. This means that conditions are better because of the diversity of types of bacteria in the cultivation environment so that cell communication of pathogenic bacteria can be inhibited and not reach the quorum. According to Defoirdt, (2007) that Vibrio sp bacteria is one of the triggers for the emergence of diseases in ponds. The existence of this bacterium must always be monitored during the maintenance period because if the population has reached quorum sensing it can result in the emergence of vibrio or vibriosis disease.

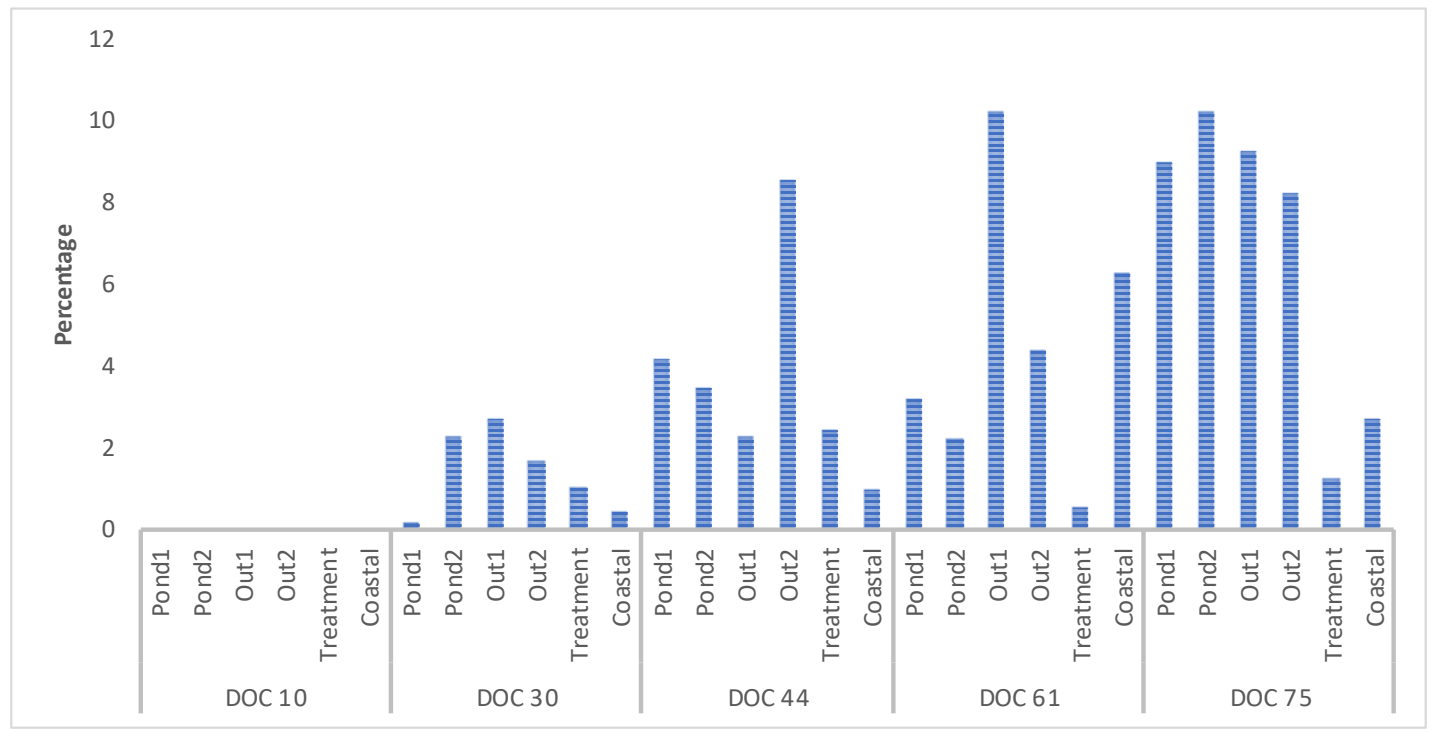

Fig.3: The ratio of $T B V$ and $T B$ at the Research Location

Whole cultivation management should have thought about how to minimize the risk of increasing the incidence of disease attacks including those caused by bacterial. The bacterial disease that causes death in the larval phase and post-penaid shrimp larvae is vibriosis. Vibriosis is a disease caused by one or several strains of vibrio pathogenic bacteria such as $V$. alginolyticus, $V$. damsela, $V$. parahaemolyticus, $V$. vulnicus, $V$. penaecida (Lightner, 1992; Anderson et al., 1988; Song et al., 1993; Lee et al., 1996).

In figure 3, even though the $\mathrm{TBV}$ and $\mathrm{TB}$ ratio at the farm outlet is quite high, it is still below $10 \%$ so that it can be said that the concentration of Vibrio bacteria is not dangerous for the cultivated shrimp. Based on the TBV and TB ratio data obtained during the maintenance period, it is seen that the ratio of the IPAL outlets is the lowest compared to the TBV and TB ratios at farm outlets. This shows that the performance of water treatment installation proved to be quite significant in reducing the ratio during the sampling period. According to Atmomarsono et al., (2013), if the TBV and TB ratio increases by more than
$10 \%$, then some Vibrio pathogens will be dangerous for cultivated shrimp.

\section{CONCLUSION}

The existence of super intensive ponds for vaname shrimp cultivation in Takalar Regency shows the dynamics of the concentration of vibrio bacteria which has the potential to cause disease in shrimp. The high density of cultivation shows an increase in the concentration of vibrio bacteria in ponds, but with the presence of water treatment installation can reduce the concentration of vibrio bacteria from the pond before discharge of water is released back to coastal waters. Super intensive technology cultivation management requires water treatment installation to minimize the concentration of vibrio bacteria.Decreasing the concentration of vibrio bacteria through WWTP can be labeled well .

\section{REFERENCES}

[1] Anderson, IG, Shamsudin, MN, Shariff, M., Nash, G. 1988. Bacterial septicemia in juvenile tiger shrimp, 
Penaeusmonodon, cultured in Malaysian brackishwater ponds. Asian Fish. Sci. 2 _1., 93-108

[2] Anshary, Hilal. 2016. Fish Parasitology, Biology, Identification and Control. Deepublish. Yogyakarta. 279 things.

[3] Atmomarsono, M., Muliani, Nurbaya, Susianingsih, E, Nurhidayah and Rachmansyah. 2013. Increased production of tiger shrimp in traditional ponds plus RICA probiotic application. The 2013 Marine and Fisheries Technology Research and Development Agency Recommendation Book. KKP. Pp. 33-43 ...

[4] Austin, B., \& Zhang, XH (2006) . Vibrio Harveyi: a significant pathogen of marine vertebrates and invertebrates. Lett. Appl. Microbiol., 43, 119-124.

[5] Azizunnisa, Smt., K.Sreeramulu . 2013. A Study On Luminiscent Bacteria In Shrimp Post Larvae In Hatcheries \& Rearing Tanks In East Godavari District Of Andhra Pradesh, India. International Journal of Advancements in Research \& Technology, Volume 2, Issue4, April-2013 .

[6] Benson, HJ 1985. Microbiological Applications: A Laboratory Manual in General Microbiology. Fourth Edition. Wm.C. Brown Publishers. Dubuque, Iowa, 450 pp.

[7] Defoirdt, T. 2007. Quorum sensing disruption and the use of short-chain fatty acids and polyhydroxyalkanes to luminescent control Vibriosis. PhD thesis, Ghent University, Belgium. p. 228.

[8] FAO. 2018. The State of World Fisheries and Aquaculture 2018 - Meeting the sustained inable development goals. Rome. License: CC BY-NC-SA 3.0 IGO .

[9] Lee, KK, Yu, SR, Chen, FR, Yang, TI, Liu, PC 1996. Virulence of Vibrio alginolyticus isolated from diseased tiger prawn, Penaeusmonodon Curr. Microbiol. 32, 229-231.

[10] Lightner, DV 1992. Shrimp pathology: major diseases of farming industry in the Americas. Mem. Congr. Ecuat. Acuicult., 177-195.

[11] RachmanSyah. 2014. Estimation of Waste Load and Management System for Super Intensive Vaname Shrimp Cultivation. Exposure to Keynote Speaker at the VI Aquaculture Innovation Forum, Bandung 6 - 8 M ay 2014.

[12] Rachman Syah., Makmur, Muhammad ChaidirUndu . 2014. Estimated Waste of Feed Nutrients and Carrying Capacity of Coastal Areas for SuperintensiveVaname Shrimp Farms . J urnal Ris etAquaculture Vol. 9 No. 3 of 2014: 439448 .

[13] Song, YL, Lee, SP 1993. Characterization and ecological implication of luminous Vibrio Í eyi isolated from tiger shrimp__Penaeus_monodon ... Bull. Inst. Zool., Acad. Sin. 32, 217-220.

[14] Taslihan, A, Ani W, Retna H, \& SM Astuti. (2004). Disease Control in Brackish Water Aquaculture, Directorate General of Fisheries Center for Jepara Brackish Water Cultivation.
[15] Tidwell, James H. 2012. Characterization and Categories of Aquaculture Production System. In Aquaculture Production System (eds: James H. Tidwell). World Aquaculture Society. Wiley Blackwell, John Wiley and Sons Publication. USA. 